\title{
ACE Polymorphism in Colorectal Cancer Patients of Kashmiri Population - A Short Report
}

\author{
A. Syed Sameer ${ }^{1,2}$, Saniya Nissar ${ }^{1}$, Samina Bashir $^{1}$, Arif Bashir ${ }^{1}$ and Mushtaq A. Siddiqi*,1 \\ Departments of ${ }^{1}$ Immunology and Molecular Medicine and ${ }^{2}$ Clinical Biochemistry; Sher-I-Kashmir Institute of Medical \\ Sciences, Soura, Srinagar, Kashmir, India
}

\begin{abstract}
Aims: The angiotensin-converting enzyme (ACE) gene in humans has an insertion-deletion (I/D) polymorphic state in intron 16 on chromosome 17q23. This polymorphism has been widely investigated in different cancers and has been implicated as the risk factor for the development of various cancers. To investigate the ACE I/D genotype frequency in CRC cases in Kashmiri population and to correlate it with the known clinicopathological characters of CRC cases.

Methods: We designed a case control study, where 86 CRC cases were studied for ACE I/D polymorphism against 150 controls taken from general population. The polymorphisms of ACE gene were investigated using polymerase chain reaction for detection of an I/D polymorphism.

Results: Among CRC (86) cases we found the frequency of ACE DD genotype to be $41.86 \%$ (36/86), II 13.95\% (12/86) and DI $44.2 \%$ (38/86). There was no significant association between the ACE I/D genotype with any of the known clinicopathological characters.
\end{abstract}

Conclusion: The ACE I/D polymorphism is not a significant risk factor in the CRC carcinogenesis in our population.

Keywords: Colorectal Cancer, ACE, Polymorphism, Kashmir.

\section{INTRODUCTION}

Colorectal cancer (CRC) is one of the leading malignancies and is the major cause of mortality and morbidity worldwide. CRC is the fourth most common cancer in men and the third most common cancer in women worldwide [1]. So far now Kashmir has been reported as a high-incidence area of GIT cancers [2,3]. In Kashmir valley CRC represents the third most common GIT cancer after esophageal and gastric $[4,5]$.

Angiotensin-converting enzyme (ACE), a key zinc metallo-enzyme of the rennin-angiotensin system is widely distributed in body [6]. The ACE catalyzes the conversion of angiotensin I into the biologically active peptide, angiotensin II, which is involved in the control of fluid-electrolyte balance and systemic blood pressure [7]. Angiotensin II is a potent vasoconstrictor and also mediates cell growth and proliferation by stimulating various cytokines and growth factors [8].

The ACE gene is located on long arm of chromosome 17 (17q23.3), the gene is 21 kilo bases (kb) long and comprises 26 exons and 25 introns. More than 160 ACE gene polymorphisms have been reported so far and most of which are single nucleotide polymorphisms (SNPs). Only 34 of these polymorphisms are located in coding region of this gene [9]. Rigat et al., [10] is the first to report the insertion/deletion (I/D) polymorphism of ACE. This polymor-

*Address correspondence to this author at the Department of Immunology and Molecular Medicine, Sher-i-Kashmir Institute of Medical Sciences, Soura, Srinagar, Kashmir, 190011 India; Tel: PABX +91-194-2401013, Ext: 2262; Fax: +91-194-2403470; Cell: +91 9419767768;

E-mail:vc.tmuk@gmail.com phism is characterized by the presence (insertion) or absence (deletion) of a $287 \mathrm{bp}$ Alu Ya5 element inside intron 16 producing three genotypes (II homozygote, $I D$ heterozygote and $D D$ homozygote). Although the I/D polymorphism is located in a non-coding region (i.e. intron) of the ACE gene, several investigators have found that the $D$ allele is related to increased activity of ACE in serum. The highest serum ACE activity was seen in the $D D$ genotype while the lowest was seen in the II genotype [11].

Several diseases including coronary heart diseases [12], stroke [13], hypertension [14] and diabetes mellitus [15] have been shown to be associated with the ACE I/D polymorphism. A number of studies have been carried out lately on association of ACE I/D polymorphism with various cancers proving that angiotensin II is a key enzyme involved in neovascularization, cell proliferation, inflammation, and cell adhesion [16-21]. Ace gene polymorphism has been reported to be implicated in pancreatic [22], prostate [23,24], breast [25], lung [26], gastric [27], esophageal [28] as well as in CRC $[18,29,30]$.

Therefore, we carried out a case-control study in our population to determine if this ACE I/D polymorphism is associated with an altered risk of developing CRC. We also investigated whether there was a link between the clinicopathological variables with the ACE genotype and hence their role in CRC predisposition.

\section{MATERIALS \& METHODS}

\section{Study Population}

This study included 86 CRC cases. All patients were recruited from Department of Surgery of our Institute. Blood 
Table 1. Primers for ACE Gene Polymorphism

\begin{tabular}{|c|c|c|c|}
\hline Target Codon & Sequence & Amplicon (bp) & $\mathbf{T}_{\mathrm{m}}\left({ }^{\mathrm{o}} \mathrm{C}\right)$ \\
\hline $\mathrm{ACE}$ & $\begin{array}{l}\text { F 5'-CTGGAGACCACTCCCATCCTTTCT -3' } \\
\text { R 5'- GATGTGGCCATCACATTCGTCAGAT -3' }\end{array}$ & $\begin{array}{l}\text { 490bp for II } \\
\text { 190bp for DD }\end{array}$ & 58 \\
\hline ACE I & $\begin{array}{l}\text { F5-TGGGACCACAGCGCCCGCCACTAC -3, } \\
\text { R5- TCGCCAGCCCTCCCATGCCCATAA-3, }\end{array}$ & $335 \mathrm{bp}$ & 67 \\
\hline
\end{tabular}

samples of 160 age and sex matched cases with no signs of any cardiac disease or diabetes were collected to serve as external controls. The controls were previously interviewed and only those who fulfilled the predetermined age/sex group were selected after obtaining the consent to participate in the study. The controls belonged to the same racial Kashmiri population of which the cases belonged. The mean age of both patient and control groups was 52 years. See Table 1 for details.

Data on all CRC patients were obtained from personal interviews with patients or guardians and medical records. All patients or guardians were informed about the study and their will to participate in this study was taken on predesigned questionnaire (Available on request). The collection and use of blood samples (from patients and controls) for this study were previously approved by the appropriate Institutional Ethics Committee.

\section{DNA Extraction \& Polymerase Chain Reaction}

DNA extraction was performed using Ammonium Acetate Method. Polymorphism in intron 16 of the $A C E$ gene was assessed by polymerase chain reaction (PCR) under conditions that have been previously described

The specific segment of ACE gene was amplified by using the previously reported primers (Salem AH et al., 2009) which amplified 190bp amplicon in case of homozygous DD genotype, 490bp in case of homozygous II genotype and both in case of heterozygous DI genotype (Fig. 1). All samples that were identified initially as a $D D$ genotype were reanalyzed using an insertion-specific primer pair, as reported by Lindpaintner et al. [31], except that the annealing temperature was $67^{\circ} \mathrm{C}$. A $335 \mathrm{bp}$ band was obtained only in the presence of the $I$ allele and no bands were detected for samples with $D D$ genotype. PCR was carried out in a final volume of $25 \mu \mathrm{L}$ containing $50 \mathrm{ng}$ genomic DNA template,

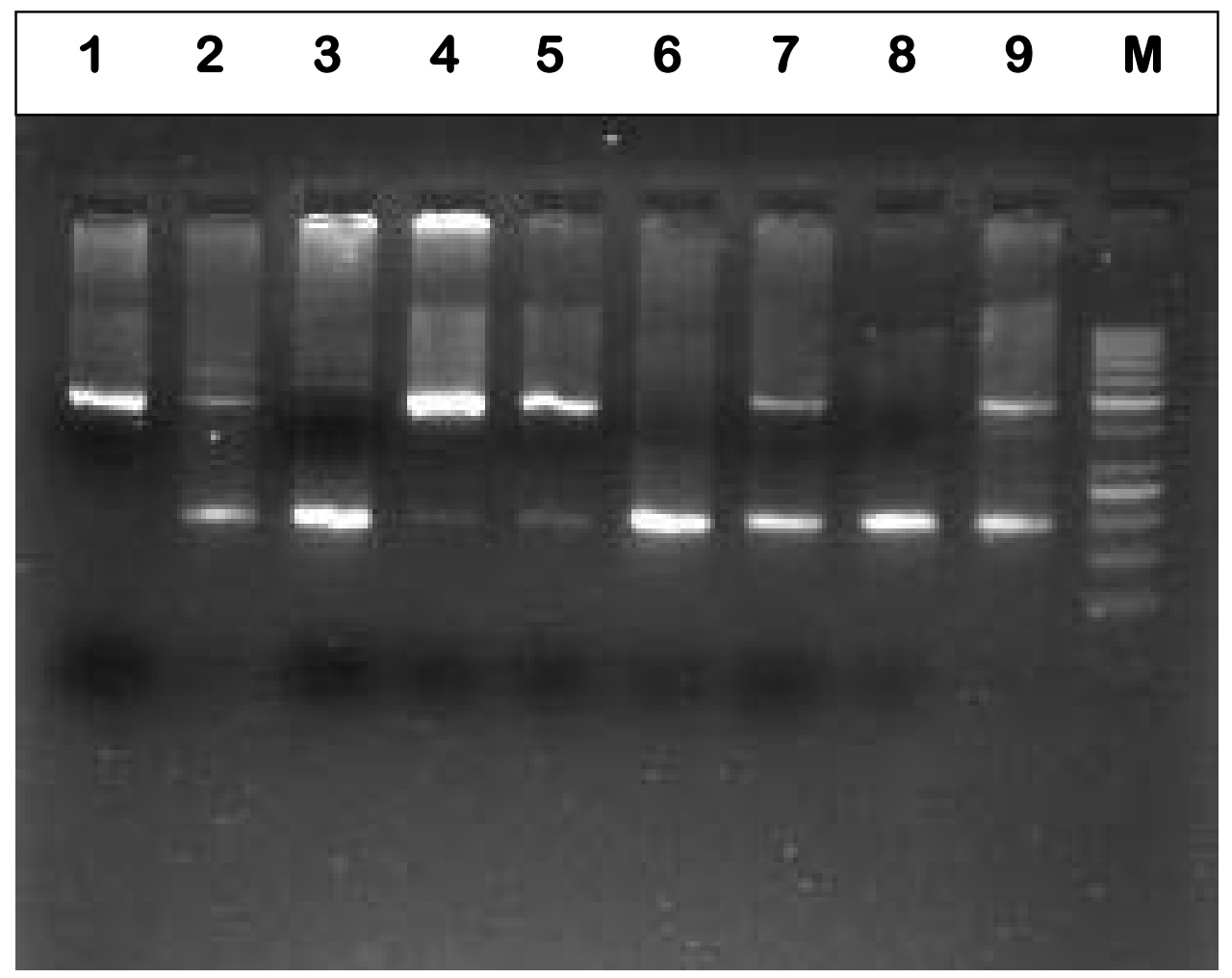

Fig. (1). Representative gel picture of $A C E$ DI polymorphism by differential amplification of intron 16 of the $A C E$ gene.

Lane M: 50bp ladder.

Lane 1 shows II form,

Lanes 2, 4, 5, 7 \& 8 show DI form and.

Lanes 3, $6 \& 8$ show DD form. 
1X PCR buffer (Fermentas) with $2 \mathrm{mM} \mathrm{MgCl}_{2}, 0.4 \mu \mathrm{M}$ of each primer (Genescript), $50 \mu \mathrm{M}$ dNTPs (Fermentas) and 0.5 U DNA polymerase (Fermentas). For PCR amplification, the standard program was used as follows: one initial denaturation step at $94^{\circ} \mathrm{C}$ for $7 \mathrm{~min}$, followed by 30 denaturation cycles of $30 \mathrm{~s}$ at $94^{\circ} \mathrm{C}, 45 \mathrm{~s}$ of annealing at $58^{\circ} \mathrm{C}$, and $45 \mathrm{~s}$ of extension at $72^{\circ} \mathrm{C}$, followed by a final elongation cycle at $72^{\circ} \mathrm{C}$ for $7 \mathrm{~min}$.

DNA amplicons were electrophoresed through a 2-3\% agarose gel for resolution. The genotypes of $>20 \%$ of the samples were double blindly reassessed to confirm the results by two independent researchers. A positive control for each polymorphism was used for $50 \%$ of samples.

\section{Statistical Analysis}

Observed frequencies of genotypes in hypertensive patients were compared to controls using chi-square or Fisher exact tests when expected frequencies were small. The chisquare test was used to verify whether genotype distributions were in Hardy-Weinberg equilibrium. Statistical significance was set at $\mathrm{P}<0.05$. Statistical analyses were performed with PASW version 18 Software.

\section{RESULTS}

A total of 86 CRC cases and 160 control subjects were included in this study. The patients comprised 49 males and 37 females $(\mathrm{M} / \mathrm{F}$ ratio $=1.32)$ and the control subjects consisted of 88 males and 72 females $(\mathrm{M} / \mathrm{F}$ ratio $=1.2)$. Mean age in patient and control groups was 52 years. No significant gender- or age-related differences were observed between the groups $(\mathrm{P}>0.05)$. Further more, out of 86 confirmed cases of CRC, 81 cases were sporadic, 4 were FAP and one case was HNPCC. All but one case was adenocarcinoma and only one was squamous cell carcinoma (SCC) of basal cell type, 59 rural and 27 urban, 36 cases had carci- noma in colon and 50 in rectum and 55 were smokers and 31 non smokers. See Table 2 for further details.

In this study, among CRC (86) cases we found the frequency of ACE DD genotype to be $41.86 \%(36 / 86)$, II $13.95 \%(12 / 86)$ and DI $44.2 \%(38 / 86)$, while as in general control (160) population the DD frequency is $53.75 \%$ (86/160), II $13.13 \%(21 / 160)$ and DI $33.13 \%(53 / 160)$. The association of ACE I/D polymorphism with the CRC cases was not found to be significant ( $p>0.05$ ) (Table 3).

We also found the hazard ratio of ACE DI genotype in CRC cases to be 1.7 times and of ACE II genotype in CRC to be 1.36 times that of general control population; indicating thereby that ACE I allele is associated with the increased risk of CRC development (Table 3).

Furthermore, analysis of the ACE I/D polymorphism with that of the clinicopathological parameters did not reveal any sort of significant association. However, we observed that the DI genotype was more common in higher tumor grade cases $(24 / 38 ; 63.2 \%)$ and rectal cancers $(25 / 38$; $65.8 \%$ ) though not of significant levels statistically.

\section{DISCUSSION}

Kashmir also called Pir-e-Waer is one of the picturesque places on earth located in the northern part of India in between the Himalayas is home of one of the oldest ethnic population that has been proven beyond doubt to be exposed to a special set of environmental and dietary risks which include consumption of sun-dried and smoked fish and meat, dried and pickled vegetables, red chilli, Hakh (a leafy vegetable of Brassica family), hot noon chai (salted tea) and Hukka (water pipe) smoke $[2,4,5]$. As previously reported, the etiology and incidence of various GIT cancers in this population have been attributed to a probable exposure to nitroso compounds, amines and nitrates are reported to be

Table 2. Frequency Distribution Analysis of Selected Demographic and Risk Factors in Colorectal Cancer Cases and Controls

\begin{tabular}{|c|c|c|c|}
\hline Variable & $\begin{array}{c}\text { Cases } \\
(n=86)\end{array}$ & $\begin{array}{l}\text { Controls } \\
(n=160)\end{array}$ & $P$ Value \\
\hline \multicolumn{4}{|l|}{ Age group } \\
\hline$\leq 50$ & $30(34.9 \%)$ & $56(35.0 \%)$ & 1.00 \\
\hline$>50$ & $56(65.1 \%)$ & $104(65.0 \%)$ & \\
\hline \multicolumn{4}{|l|}{ Gender } \\
\hline Female & $37(43.0 \%)$ & $72(45.0 \%)$ & 0.76 \\
\hline Male & $49(67.0 \%)$ & $88(55.0 \%)$ & \\
\hline \multicolumn{4}{|l|}{ Dwelling } \\
\hline Rural & $59(68.6 \%)$ & $104(65.0 \%)$ & 0.56 \\
\hline Urban & $27(31.4 \%)$ & $56(35.0 \%)$ & \\
\hline \multicolumn{4}{|l|}{ Smoking status } \\
\hline Never & $31(36.0 \%)$ & $75(46.8 \%)$ & 0.10 \\
\hline Ever & $55(64.0 \%)$ & $85(53.2 \%)$ & \\
\hline \multicolumn{4}{|l|}{ Pesticide Exposure } \\
\hline Never & $33(38.4 \%)$ & $75(46.8 \%)$ & 0.20 \\
\hline Ever & $53(61.6 \%)$ & $85(53.2 \%)$ & \\
\hline
\end{tabular}


Table 3. Genotype Frequencies of ACE Intron 16 Gene Polymorphism in Cases \& Controls

\begin{tabular}{|c|c|c|c|c|}
\hline ACEs Genotype & $\begin{array}{c}\text { Cases } \\
(\mathbf{n = 8 6})\end{array}$ & $\begin{array}{c}\text { Controls } \\
(\mathbf{n = 1 6 0})\end{array}$ & OR (95\% CI ) & $\chi^{2} ; \mathbf{P}$ Value \\
\hline \hline DD & $36(41.86 \%)$ & $86(53.75 \%)$ & $1(\mathrm{Ref})$ & $3.47 ; 0.17$ \\
DI & $38(44.2 \%)$ & $53(33.13 \%)$ & $1.7(0.96-3.02)$ \\
II & $12(13.95 \%)$ & $21(13.13 \%)$ & $1.61(0.95-2.74)$ \\
DI+II & 50 & 74 & \\
\hline
\end{tabular}

present in these local food stuffs most of which have been shown to contain important irritant and carcinogens [3,32].

CRC being the world's third most common malignancy is also paving its way in Kashmiri population where it has increased in the last two decades to become the third most common malignancy of GIT after esophageal and gastric [5].

In one of the pioneer studies by Rocken et al. [29]. On ACE I/D polymorphism it was observed that ACE expression levels and hence the DI genotype was directly correlated with the tumor size, thus implicating the ACE as one of the risk factors to CRC development. Also in another retrospective study by the same lab on gastric cancer it was found that ID genotype of the ACE gene influences the tumor development and advancement to metastasis [27]. Also it has also been shown that ID or II genotype were at a greater risk of developing CRC than that of DD carriers [18]. Hence taking these observations into account we designed this prospective cohort study to observe the association of ACE I/D genotype and $\mathrm{CRC}$ risk in our population.

We observed the frequency of ACE DD genotype to be $41.86 \%(36 / 86)$, II $13.95 \%(12 / 86)$ and DI $44.2 \%(38 / 86)$ in CRC cases from our Kashmiri population which are in tune with the frequencies reported by other authors [18,27]. However statistically there was no significant association between the ACE I/D polymorphism with the CRC cases. These results were similar to one of the study where no relation was found between the ACE I/D polymorphism and the risk of CRC development [33,34].

However, we found cases with DI genotype to be 1.7 times and cases with II genotype 1.36 times more predisposed to CRC than that of DD genotype, overall risk of development of CRC for I allele was 1.61 times. These results were also similar to what has been already reported $[18,33]$.

We also found the DI genotype to be more common in higher tumor grade cases (24/38) and rectal cancers (25/38), highlighting the role played by ACE in development of higher advanced tumors as has been reported previously by Rocken et al. [29]. As we know ACE helps in the synthesis of Angiotensin II which in turn has been found to be a potent angiogenic factor that may participate in tumorigenesis by promoting angiogenesis in cancer cells by neovascularization, cell proliferation and cell adhesion via altered expression of angiotensin II type 1 (AT1R) and type 2 receptor (AT2R) [17,25]. This may somehow explain the relationship between the II and DI genotype with that of the higher tumor grade.

\section{CONCLUSION}

Hence in our study we conclude that although there is a correlation between the ACE I/D genotype with the higher tumor grade but the polymorphism is not a significant risk factor in the CRC carcinogenesis in our population. Thus we conclude that the ACE I/D polymorphism is negatively related to the development and progression of CRC in our Kashmiri population, these results conform to the previous studies [33,34].

\section{ACKNOWLEDGEMENT}

The authors gratefully acknowledge the financial support provided by Sher-i-Kashmir Institute of Medical Sciences, Kashmir, for this work. Our thanks is also due to the Head and Technical Staff of the operation theater of Department of General Surgery who helped us in the tissue procurement. We also thank the anonymous pathologists of Department of Pathology for the histopathological assessment of the tumor tissues.

\section{REFERENCES}

[1] Center MM, Jemal A, Smith A, Ward E. Worldwide variations in colorectal cancer. CA Cancer J Clin 2009; 59: 366-78.

[2] Mir MM, Dar NA, Gochhait S, et al. p53 Mutation profile of squamous cell carcinomas of the esophagus in Kashmir (India): a high-incidence area. Int J Cancer 2005; 116:62-8.

[3] Murtaza I, Mushtaq D, Margoob MA, et al. A study on p53 gene alterations in esophageal squamous cell carcinoma and their correlation to common dietary risk factors among population of the Kashmir valley. World J Gastroenterol 2006; 12: 4033-7.

[4] Sameer AS, Rehman S, Pandith AA, et al. Molecular gate keepers succumb to gene aberrations in colorectal cancer in Kashmiri population, revealing a high incidence area. Saudi J Gastroenterol. 2009; 15: 244-52.

[5] Sameer AS, Shah ZA, Syeed N, et al. TP53 Pro47Ser and Arg72Pro polymorphisms and colorectal cancer predisposition in ethnic Kashmiri population. Genet Mol Res 2010; 2: 651-60.

[6] Salem AH, Batzer MA. High frequency of the D allele of the angiotensin-converting enzyme gene in Arabic populations. BMC Res Notes 2009; 8: 99.

[7] Wang JG, Staessen JA. Genetic polymorphisms in the reninangiotensin system: relevance for susceptibility to cardiovascular disease. Eur J Pharmacol 2000; 410: 289-302.

[8] Carluccio M, Soccio M, De Caterina R. Aspects of gene polymorphisms in cardiovascular disease: the renin-angiotensin system. Eur J Clin Invest 2001; 31: 476-88.

[9] Sayed-Tabatabaei FA, Oostra BA, Isaacs A, van Duijn CM, Witteman JC. ACE polymorphisms. Circ Res 2006; 98: 1123-33.

[10] Rigat B, Hubert C, Alhenc-Gelas F, Cambien F, Corvol P, Soubrier F. An insertion/deletion polymorphism in the angiotensin I converting enzyme gene accounting for half the variance of serum enzyme levels. J Clin Invest 1990; 86: 1343-6.

[11] Sakuma T, Hirata RD, Hirata MH: Five polymorphisms in gene candidates for cardiovascular disease in Afro-Brazilian individuals. J Clin Lab Anal 2004; 18: 309-16. 
[12] Obineche EN, Frossard PM, Bokhari AM. An association study of five genetic loci and left ventricular hypertrophy amongst Gulf Arabs. Hypertens Res 2001; 24: 635-9.

[13] Zee RY, Ridker PM, Stampfer MJ, Hennekens CH, Lindpaintner $\mathrm{K}$. Prospective evaluation of the angiotensin-converting enzyme insertion/deletion polymorphism and the risk of stroke. Circulation 1999; 99: 340-3.

[14] Gesang L, Liu G, Cen W, et al. Angiotensin-converting enzyme gene polymorphism and its association with essential hypertension in a Tibetan population. Hypertens Res 2002; 25: 481-5.

[15] Kennon B, Petrie JR, Small M, Connell JM. Angiotensinconverting enzyme gene and diabetes mellitus. Diabet Med 1999; 16: 448-58.

[16] Nacak M, Nacak I, Sanli M, Ozkur M, Pektaş M, Aynacioğlu AS. Association of angiotensin converting enzyme gene insertion/deletion polymorphism with lung cancer in Turkey. Cancer Genet Cytogenet 2010; 198: 22-6.

[17] Deshayes F, Nahmias C. Angiotensin receptors: a new role in cancer? Trends Endocrinol Metab 2005; 16: 293-9.

[18] van der Knaap R, Siemes C, Coebergh JW, van Duijn CM, Hofman A, Stricker BH. Renin-angiotensin system inhibitors, angiotensin Iconverting enzyme gene insertion/deletion polymorphism, and cancer: the Rotterdam Study. Cancer 2008; 112: 748-57.

[19] Bauvois B. Transmembrane proteases in cell growth and invasion: new contributors to angiogenesis? Oncogene 2004; 23: 317-29.

[20] Yoshiji H, Kuriyama S, Fukui H. Angiotensin-I - converting enzyme inhibitors may be an alternative anti-angiogenic strategy in the treatment of liver fibrosis and hepatocellular carcinoma. Possible role of vascular endothelial growth factor. Tumour Biol 2002; 23: 348-56

[21] Fujita M, Hayashi I, Yamashina S, Itoman M, Majima M. Blockade of angiotensin ATla receptor signaling reduces tumor growth, angiogenesis, and metastasis. Biochem Biophys Res Commun 2002; 294: 441-7.

[22] Fendrich V, Chen NM, Neef M, et al. The angiotensin-I-converting enzyme inhibitor enalapril and aspirin delay progression of pancreatic intraepithelial neoplasia and cancer formation in a genetically engineered mouse model of pancreatic cancer. Gut 2010; 59: 630-7.

[23] Uemura H, Ishiguro H, Nakaigawa N, et al. Angiotensin II receptor blocker shows antiproliferative activity in prostate cancer cells: a possibility of tyrosine kinase inhibitor of growth factor. Mol Cancer Ther 2003; 2: 1139-47.

[24] Sierra Díaz E, Sánchez Corona J, Rosales Gómez RC, et al. Angiotensin-converting enzyme insertion/deletion and angiotensin type receptor A1166C polymorphisms as genetic risk factors in benign prostatic hyperplasia and prostate cancer. J Renin Angiotensin Aldosterone Syst 2009; 10: 241-6.

[25] Puddefoot JR, Udeozo UK, Barker S, Vinson GP. The role of angiotensin II in the regulation of breast cancer cell adhesion and invasion. Endocr Relat Cancer 2006; 13: 895-903.

[26] Feng Y, Wan H, Liu J, et al. The angiotensin-converting enzyme 2 in tumor growth and tumor-associated angiogenesis in non-small cell lung cancer. Oncol Rep 2010; 23: 941-8.

[27] Röcken C, Lendeckel U, Dierkes J, et al. The number of lymph node metastases in gastric cancer correlates with the angiotensin I converting enzyme gene insertion/deletion polymorphism. Clin Cancer Res 2005; 11: 2526-30.

[28] Lang L. ACE inhibitors may reduce esophageal cancer incidence. Gastroenterology 2006; 131: 343-4.

[29] Röcken C, Neumann K, Carl-McGrath S, et al. The gene polymorphism of the angiotensin I-converting enzyme correlates with tumor size and patient survival in colorectal cancer patients. Neoplasia 2007; 9: 716-22.

[30] Neo JH, Ager EI, Angus PW, Zhu J, Herath CB, Christophi C. Changes in the renin angiotensin system during the development of colorectal cancer liver metastases. BMC Cancer 2010; 10: 134.

[31] Lindpaintner K, Pfeffer MA, Kreutz R, et al. A prospective evaluation of an angiotensin-converting-enzyme gene polymorphism and the risk of ischemic heart disease. N Engl J Med 1995; 332: 70611 .

[32] Siddiqi M, Kumar R, Fazili Z, Spiegelhalder B. Increased exposure to dietary amines and nitrate in a population at high risk of esophageal and gastric cancer in Kashmir (India). Carcinogenesis 1992; 13: 1331-5.

[33] Toma M, Cimponeriu D, Apostol P, et al. Lack of association between ACE ID polymorphism and colorectal cancer in Romanian patients. Chirurgia (Bucur) 2009; 104: 553-6.

[34] Nikiteas N, Tsigris C, Chatzitheofylaktou A, Yannopoulos A. No association with risk for colorectal cancer of the insertion/deletion polymorphism which affects levels of angiotensin-converting enzyme. In Vivo 2007; 21: 1065-8. 